\title{
Fluctuations of Glaciar Esperanza Norte in the north Patagonian Andes of Argentina during the past $400 \mathrm{yr}$
}

\author{
L. Ruiz, M. H. Masiokas, and R. Villalba \\ Instituto Argentino de Nivología, Glaciología y Ciencias Ambientales (IANIGLA), CCT Mendoza-CONICET, \\ C.C. 330 (5500) Mendoza, Argentina \\ Correspondence to: L. Ruiz (lruiz@mendoza-conicet.gob.ar)
}

Received: 20 October 2011 - Published in Clim. Past Discuss.: 26 November 2011

Revised: 25 May 2012 - Accepted: 1 June 2012 - Published: 27 June 2012

\begin{abstract}
The number of studies of Little Ice Age (LIA) glacier fluctuations in southern South America has increased in recent years but is largely biased towards sites in the south Patagonian Andes. In this paper we present a detailed record of length and areal fluctuations of Glaciar Esperanza Norte (GEN) in the north Patagonian Andes of Argentina during the past four centuries. The GEN record was reconstructed through the dendro-geomorphological dating of moraines and the analysis of satellite imagery, aerial photographs and documentary material complemented with extensive field surveys. The maximum LIA extent at GEN was associated with an outer moraine dated to the mid 17th century. At least 19 subsequent readvances or standstills evidenced by morainic ridges were identified inside the most extensive LIA moraine. The dating and spacing of these moraines and the additional information available indicate that the ice front retreated much more rapidly during the 20th century than during earlier centuries. Comparison with the record of LIA fluctuations of Glaciar Frías, an ice mass of similar characteristics located $110 \mathrm{~km}$ to the north of GEN, shows a similar pattern of recession over the past $400 \mathrm{yr}$. Both glacier records have the peak LIA event occurring roughly during the same interval (early-mid 17th century) and show a minor readvance during the 1970s, but there are still a few discrepancies in the dating of some inner moraines. These differences may be due to local, specific factors or associated with the inherent uncertainties in the dating of the moraines. The chronologies of GEN and Frías are among the most detailed currently available in Patagonia, but a larger number of study sites is needed to develop robust, regionally representative glacier chronologies. Detailed glaciological, geomorphological and meteorological data are also needed to understand the glacier-climate relationships in this region and develop reliable paleoclimatic reconstructions.
\end{abstract}

\section{Introduction}

Glaciers in many mountainous regions of the world have shown a generalized pattern of recession during the 20th century. This retreating trend started at the end of the Little Ice Age (LIA; Grove, 1988), a period of widespread glacier advances culminating between the 16th and 19th centuries in Patagonia and other regions. The recent pattern of glacier mass losses is concurrent with a period of increasing temperatures in most regions, supporting the notion that glaciers can be used as key indicators of regional and larger-scale climatic changes (Haeberli, 1994; Oerlemans, 2005; IPCC, 2007). Indeed, several previous studies have developed paleoclimatic reconstructions from records of glacier length fluctuations compiled across different continents (e.g. Oerlemans, 2005; Leclercq and Oerlemans, 2011). For some areas such as the European Alps, the number of detailed, well-dated glacier chronologies is relatively large and therefore the climatic information derived from these records could be considered a reliable and representative measure of the region's climate changes over the past centuries. In less known areas, deriving reliable paleoclimatic information from glaciers will remain a very difficult task until more glaciers are studied and carefully dated records of frontal or areal fluctuations are developed.

In southern South America, the number of glacier chronologies of LIA and post-LIA variations has increased in recent years (see e.g. Masiokas et al., 2009 and references therein). However, and especially in the northern portion of the Patagonian Andes, the number of sites under investigation is still very limited and a regional pattern of glacier fluctuations has yet to emerge. There is however a great potential for developing detailed glacier chronologies. During the LIA most glacier tongues extended below treelines, affecting 
forests and leaving moraines that can be dated through dendrochronological, lichenometric and other types of dating techniques (see e.g. Luckman, 2000). The evidence available for the last $1000 \mathrm{yr}$ indicates that in southern South America there is considerable variability in the extent and timing of glacier events related to the maximum LIA expansion. In this respect, new detailed information regarding the history of fluctuations of north Patagonian glaciers is crucial for improving the existing glacier chronologies and ultimately for making reliable paleoclimatic inferences from these records.

In this paper we present a record of frontal variations during the past $400 \mathrm{yr}$ for Glaciar Esperanza Norte (GEN), a temperate valley glacier located at the core of the north Patagonian Andes (42 $2^{\circ} 50^{\prime \prime} \mathrm{S}, 72^{\circ} 3^{\prime} 12.5^{\prime \prime} \mathrm{W}$; Fig. 1). Like most relatively small temperate glaciers located in mountain ranges with high precipitation, GEN is probably highly sensitive to climate variations. Therefore, the record of fluctuations of GEN could provide valuable information regarding the glacier and climate history in this poorly known portion of the north Patagonian Andes. The record of frontal variations of GEN (Fig. 2) has been reconstructed using a variety of sources, including dendro-geomorphological analyses, remote sensing, field measurements and historical photographs. The resulting glacier chronology is compared with other glacier records from northern Patagonia in an attempt to identify a possible common pattern of fluctuations over the past $400 \mathrm{yr}$.

\section{Previous studies}

In the north Patagonian Andes (i.e. between ca. $37^{\circ}$ and $45^{\circ} \mathrm{S}$, Fig. 1), the chronologies of glacier fluctuations covering the past millennium are limited. To date, most efforts have been concentrated at the glaciers of Monte Tronador (Fig. 1), about $110 \mathrm{~km}$ to the north of GEN. Monte Tronador is a $3484 \mathrm{~m}$, high peak shared by Chile and Argentina with an ice cap and several discharging glaciers that cover a total area of ca. $63 \mathrm{~km}^{2}$ in 2011 (A. Rivera, personal communication, 2012). At this site, frontal variations since the LIA have been documented for Glaciar Río Manso, Castaño Overo and Frías on the Argentinean side (Rabassa et al., 1984; Villalba et al., 1990; Masiokas et al., 2010; Zemp et al., 2011). Rabassa et al. (1978a) provide a detailed account of the 20th century behavior of Tronador glaciers on the Argentinean side, and Bown and Rivera (2007) studied the frontal and surface elevation changes of the Chilean Glaciar Casa Pangue during the 20th century. The available information indicates that Glaciar Frías reached the LIA maximum extent in the early 17th century, whereas at Río Manso and Castaño Overo this occurred in the 19th century. Over the 20th century all glaciers have experienced a very noticeable frontal retreat and thinning (Masiokas et al., 2009). A minor readvance culminating in 1976-1977 has been identified at most sites: at Frías this advance has been very well documented by

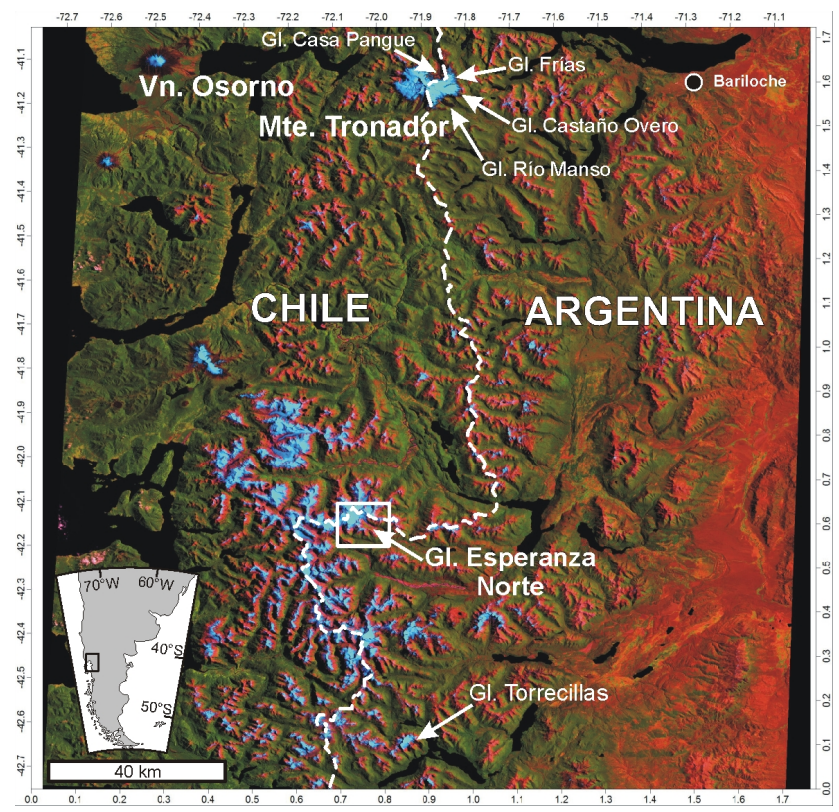

Fig. 1. Map showing the location of the study area and Glaciar Esperanza Norte in the north Patagonian Andes of Argentina. Other glaciers discussed in the text are indicated. The background image is a composite (bands 541) RGB Landsat TM scene acquired in late February 1987.

field measurements and dendro-geomorphological determinations (Rabassa et al., 1978a; Villalba et al., 1990). Leclercq et al. (2011) provide a climatic interpretation of the length variations of Glaciar Frías since the LIA using a combination of a simplified surface energy-balance model and a flowline model to account for the dynamical response of the glacier to changes in the climatic forcing. Moraine formation since the LIA has also been dated through dendrochronology and lichenometry for Glaciar Torrecillas, a small mountain glacier located $65 \mathrm{~km}$ to the south of GEN (Garibotti and Villalba, 2009). In this case the LIA maximum extent was dated to late 16 th-early 17 th centuries. Other glaciers in northern Patagonia have also been studied mainly through remote sensing techniques, and in general they have experienced frontal and volume losses over the past few decades (Masiokas et al., 2009).

\section{Study area}

In the north Patagonian Andes, the seasonal variations in precipitation are largely modulated by the location and intensity of the Southern Hemisphere westerlies. During the warm season, the Westerlies at surface $(925 \mathrm{hPa})$ are stronger but concentrated further south between ca. $45^{\circ}$ and $55^{\circ} \mathrm{S}$, whereas during the cold season they expand to the north thus bringing most of the precipitation to northern Patagonia during the winter months (Villalba et al., 2003; Garreaud 


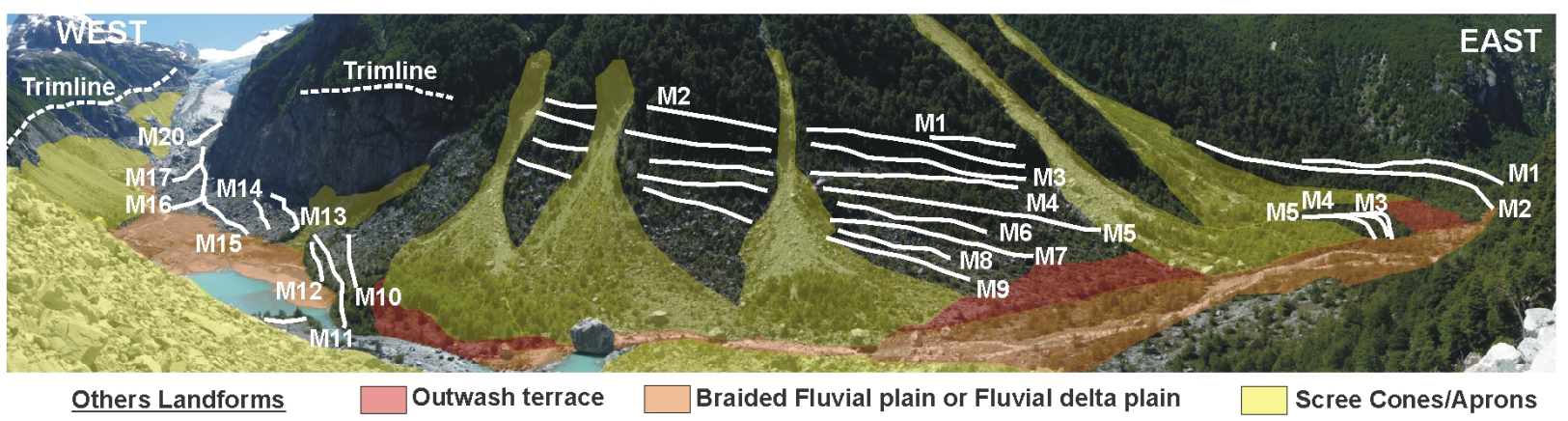

Fig. 2. Panoramic view of the upper Río Esperanza valley seen from the south. Glaciar Esperanza Norte is on the far left and the moraines are indicated with white lines (see also Fig. 3). Note the distortion of the view due to the curvature of the valley. The distance between M1 to M11 is ca. $1.24 \mathrm{~km}$ and the distance between M11 and the glacier front is ca. $2.4 \mathrm{~km}$. The location where the photo was taken is shown in Fig. 4.

et al., 2009). Steep west-east precipitation gradients can be observed in the study area due to the blocking effect that the Andes (with north-south orientation) exert on the dominant atmospheric westerly flow (Miller, 1976; Prohaska, 1976). Although there are no direct, reliable meteorological measurements, several meters of annual precipitation have been estimated at the highest peaks along the north Patagonian Andes (Gallopín, 1978; Leclercq et al., 2011). Precipitation totals decrease dramatically only a few $\mathrm{km}$ to the east and a very large contrast in vegetation cover can be observed between the thick dense forests on the western Andean slopes and the arid low shrublands in the eastern Patagonian steppe. This drastic precipitation gradient across the Andes also determines that, in general, the western peaks located nearer the ocean support a larger glaciated area than their eastern, drier neighbors. At the latitudes of GEN (ca. $42^{\circ} \mathrm{S}$ ), mean annual temperatures are around $10^{\circ} \mathrm{C}$ on the Chilean lowlands, $6^{\circ} \mathrm{C}$ in the subalpine deciduous forest near treeline, and $8^{\circ} \mathrm{C}$ in the steppe-forest transition east of the Andes (Almeyda and Saez, 1958; Gallopín, 1978). Annual thermal amplitudes across this region vary widely as they depend on altitude, aspect, and proximity to the ocean, with generally larger amplitudes on the eastern slopes and the Patagonian steppe than on the Chilean side of the Andes nearer to the ocean. For some west-exposed sites, at $42^{\circ} \mathrm{S}$ the average diurnal temperature range is ca. $6^{\circ} \mathrm{C}$, whereas for other sites within the cordillera or further east in the Patagonian plains this range can be ca. $10^{\circ} \mathrm{C}$ or more (Villalba et al., 2003). Although Falvey and Garreaud (2009) report no noticeable near surface air temperature trends between 1979 and 2006 at Puerto Montt (Fig. 1), Bown and Rivera (2007) and Carrasco et al. (2008) found a warming trend in the upper troposphere (radiosonde data measured between 900 and $1500 \mathrm{~m}$ a.s.l.) over the past decades. The warming trend was observed at the elevation of the lower tongues of the Tronador glaciers and could at least partly explain, together with the concurrent decrease in precipitation recorded in the region, the recent regional pattern of recession observed in north Patagonian glaciers (Masiokas et al., 2009; Rivera et al., 2012).

With a mean maximum elevation of $2000 \mathrm{~m}$, major peaks in the north Patagonian Andes are related to Pleistocene or active volcanoes including the Tronador (3484 $\mathrm{m}$ a.s.l.) and Osorno (2652 m a.s.l., last eruption in 1869, Gonzáles Ferrán, 1995) (Fig. 1). Traditionally, it was assumed that the largest glaciers were almost exclusively present on the volcanoes overpassing the mean maximum elevation (Lliboutry, 1956, 1999). However, recent remote sensing reconnaissance has allowed the identification and inventorying of relatively large glaciers ( $>10 \mathrm{~km}^{2}$ in size) at lower elevations. These glaciers are located in remote areas of the northern Patagonian Andes between $42^{\circ} \mathrm{S}$ and $43^{\circ} \mathrm{S}$ (Ruiz, 2012). Most of these large remote glaciers are valley glaciers with compound basins that terminate at elevations as low as $1000 \mathrm{~m}$. Rivera et al. (2012) have found glaciers in this region that reach minimum elevations as low as $550 \mathrm{~m}$ a.s.l. Although no local meteorological information is available for most of these glaciers, there have been a few attempts (Condom et al., 2007; Carrasco et al., 2005 and 2008) to constrain the climatic Equilibrium Line Altitude (ELA) at a regional scale based on meteorological data from low altitude stations and scarce mass balance data (Rivera et al., 2006). These studies indicate that the climatic ELA in the region is around 1400 and $2000 \mathrm{~m}$, suggesting that the abundant precipitation of the area would result in an ELA below the $0^{\circ} \mathrm{C}$ isotherm. Carrasco et al. (2008) found a rise in the climatic ELA in the region during the last $20 \mathrm{yr}$, which they relate to a concurrent rise in the $0^{\circ} \mathrm{C}$ isotherm.

GEN was initially included in the World Glacier Inventory (ID: RA1L00300041) in the year 1978 (Rabassa et al., 1978b). Using aerial photographs, its area was estimated in $6.3 \mathrm{~km}^{2}$, but this information underestimates the true area of the glacier. A recent glacier inventory based on satellite images shows a total planimetric area of $11.3 \pm 0.2 \mathrm{~km}^{2}$ and $10.7 \pm 0.2 \mathrm{~km}^{2}$ for GEN in 1987 and 2007, respectively. The maximum and minimum elevations for GEN in 2007, based on the SRTM V4 Digital Elevation Model (Jarvis et 
al., 2008), are $2400 \pm 20 \mathrm{~m}$ and $1080 \pm 20 \mathrm{~m}$, respectively. The glacier mean elevation, for the same year, has been estimated at $1850 \pm 20 \mathrm{~m}$ (Ruiz, 2012).

\section{Data and methods}

In this study the variations in length and area of GEN over the past $400 \mathrm{yr}$ have been reconstructed using a combination of sources and techniques that include field surveys, dendrogeomorphological dating of moraines, remote sensing analyses, and the use of historical documents. After first identifying the main deposits on satellite images and aerial photos, moraine crests were mapped in the field with GPS equipment and their relative relief measured or estimated when access was difficult or dangerous. This allowed the development of a detailed plani-altimetric map for the assessment of recent and historic surface and elevation changes of the glacier tongue. Whenever possible, the size distribution and shape of the clasts was measured or estimated in these morainic deposits.

Dendro-geomorphological determinations (Luckman, 2000) allowed the dating of lateral and frontal moraines located in the glacier forefield associated with LIA and postLIA events. Minimum dates of formation of the moraines were determined from the age of the oldest trees sampled on their surface. Three species - Nothofagus pumilio, Nothofagus dombeyi, and Fitzroya cupressoides - were recorded on the glacier forefield and sampled in this study. The sampling of these trees was performed with increment borers and their ages determined using standard dendrochronological procedures (Stokes and Smiley, 1996). Cores were taken as close as possible from the tree's base but except for the youngest, smallest trees the sampling height generally ranged between 0.5 and $1 \mathrm{~m}$. Previous related studies in other Patagonian glaciers (Masiokas et al., 2009, 2010) have shown that the error in estimating basal dates of Nothofagus spp. is relatively minor (i.e. $<10 \mathrm{yr}$ ) when sampling up to $1 \mathrm{~m}$ from the tree's base. In the absence of direct information from the study area, here we used these previous estimations as a reference and applied a vertical growth rate of $10 \mathrm{~cm} \mathrm{yr}^{-1}$ to correct for sampling height (Table 1). Whenever possible, for samples with no pith we also estimated pith offset values based on ring curvature. However, pith offset values where difficult to determine in samples with almost parallel inner rings. We added an arbitrary correction of $20 \mathrm{yr}$ to the dating of the innermost ring to account for missing rings in these incomplete samples. Admittedly, the dating accuracy from these samples (usually coming from old large trees with rotten centers) is poorer and contains larger inherent uncertainties than cores collected at the base of young trees reaching the pith. Although these age corrections provide a dating likely closer to the true age of the older trees, the resulting dates should be used with caution and only as approximate minimum age estimates for the moraines.

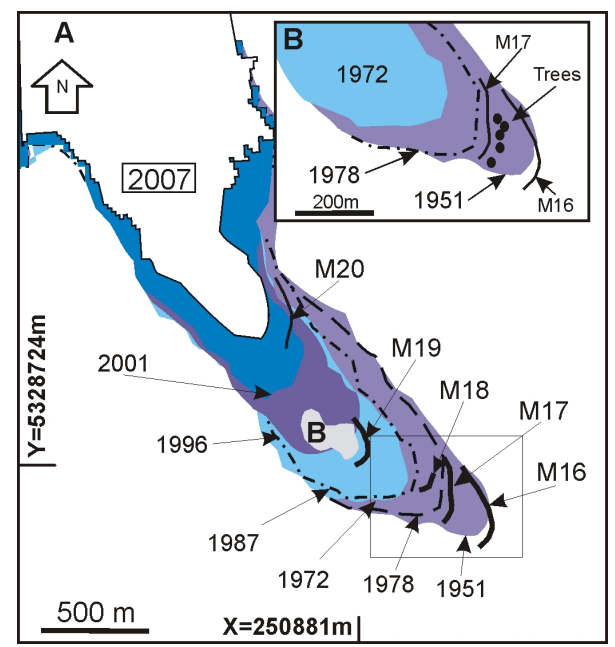

Fig. 3. (A) Fluctuations of the lower portion of Glaciar Esperanza Norte since 1951 derived from remote sensing analyses and historical photographs. The innermost moraines are shown as thick black lines, and the position of the glacier front in 1978 and 1987 is shown by dashed and dash-point black lines, respectively. The lake superior (see Fig. 4a) is shown in grey inside M19. (B) Sketch showing the information used to estimate ecesis at this site, including the location of the trees sampled on M17 and the position of the glacier in 1951, 1971 and 1978. Coordinates X and Y in UTM 19 S WGS84 projection.

The examination of the different sampling sites suggests that the selected trees constitute the first generation colonizing the deposits, but additional evidence ideally providing maximum age estimates (e.g. from trees tilted, scarred or overridden by the glacier) is needed to better define the date of formation of these moraines (see e.g. Luckman, 2000; Luckman and Villalba, 2001).

The period between moraine stabilization and seedling establishment (commonly referred to as "ecesis"; Sigafoos and Hendricks, 1969; McCarthy and Luckman, 1993) was determined as follows: The dating at the base of five small trees growing immediately outside a small bouldery frontal moraine (M17, Table 1) indicates the oldest of these trees started growing in 1971. Aerial photographs from 1951 and 1972 show that the glacier was still covering the position of M17 in 1951 but had already receded ca. $200 \mathrm{~m}$ from this moraine in 1972 (Fig. 3a and b). Based on the age of the oldest tree growing on M17, the distances between the two fixed points derived from the photographs, and assuming a constant retreating rate of the glacier front, we estimated that the first seedling germinated $13 \mathrm{yr}$ after the M17 moraine became ice-free. We applied a fixed 13-yr ecesis correction to the dating of all tree-ring based, minimum age determinations of moraines in the glacier forefield (Table 1).

In addition to the information derived from dendrochronological determinations and aerial photographs, we also used a number of satellite images, historical documents and direct 
Table 1. Dendrochronological dating of moraines at Glaciar Esperanza Norte. The number of trees and earliest ring date from the oldest tree sampled at each surface are indicated. Minimum ages were estimated after accounting for pith offset, sampling height, and a constant 13-yr ecesis correction. Minimum ages of moraines are derived from Nothofagus pumilio (lenga) except M9 that was dated using a sample from Fitzroya cupressoides (alerce).

\begin{tabular}{lllll}
\hline & \multicolumn{2}{c}{$\begin{array}{c}\text { Number of trees } \\
\text { (innermost ring date) }\end{array}$} & $\begin{array}{l}\text { Corrections (sampling } \\
\text { height-pith offset-ecesis) }\end{array}$ & $\begin{array}{l}\text { Estimated minimum } \\
\text { age for surface }\end{array}$ \\
\cline { 2 - 3 } Sampling site & North margin & South Margin & $(10-10-0)$ & $1544^{*}$ \\
Mature forest outside M1 & $19(1620)$ & $8(1564)$ & $(10-20-13)$ & 1652 \\
M1 & $19(1695)$ & $5(1730)$ & $(10-10-13)$ & 1691 \\
M2 & $44(1734)$ & $37(1724)$ & $\left(10-20 \_13\right)$ & 1795 \\
M3 & $7(1821)$ & $4(1838)$ & $(10-10-13)$ & 1792 \\
M4 & $10(1860)$ & $28(1825)$ & $(10-0-13)$ & 1830 \\
M5 & $5(1853)$ & & $(10-0-13)$ & 1807 \\
M6 & $6(1871)$ & $22(1830)$ & $\left(10-20 \_13\right)$ & 1830 \\
M7 & $5(1873)$ & & $(5-10-13)$ & 1876 \\
M8 & $5(1904)$ & & $(5-0-13)$ & 1927 \\
M9 & $1(1894)$ & & $(5-10-13)$ & 1933 \\
M12 & & $5(1955)$ & $(5-20-13)$ & 1958 \\
M13 & $5(1962)$ & $16(1964)$ & $(0-0-13)$ & \\
M17 & $5(1971)$ & & & \\
\hline
\end{tabular}

* The mature forest was sampled relatively close but outside M1 and consisted of enormous $N$. pumilio and N. dombeyi (coihue) trees with a thick bamboo understorey. In contrast, bamboo was absent in M1-M2 and inner moraines. Thirteen alerces (dates not shown) sampled on the mature forest on the north side of the valley ca. $200 \mathrm{~m}$ above the M1 limit showed significantly older ages with the innermost ring dating to 999 AD.

measurements in the field to reconstruct as reliably as possible the fluctuations of the glacier snout over the last $50 \mathrm{yr}$ (Fig. 3a). As discussed above, two sets of aerial photos are available for GEN. Both sets were taken in summer, but the 1951 set has a scale of 1:35000 whereas the 1972 set is available at a scale 1:60000. Each photograph was digitized to a resolution of $1200 \mathrm{dpi}$ and rectified using a 1987 Landsat scene using SAGA GIS (www.sagagis.com). More than 25 control points and the triangulation interpolation method were used for the rectification of the aerial photos. In order to minimize the distortion in the images that may affect areal calculations, control points were located at the edge of the photographs and near the glacier. Each rectified photo was projected into a UTM 19 South Zone, Datum WGS84 with a pixel size of 1 and $2 \mathrm{~m}$ for the 1951 and 1972 photographs, respectively. Glacier limits and other relevant morphological features such as medial or lateral moraines were digitized manually on screen.

The areas and lengths of GEN in 1987 and 2007 were obtained as part of two complementary, remote sensing regional glacier inventories (Fig. 3a). A band ratio image classification approach was used to identify and measure the glaciated area on an ortho-rectified Landsat TM scene acquired on 9 February 1987 (path 232, row 89, root mean square error ca. $50 \mathrm{~m}$, Tucker et al., 2004), and on an Aster scene from 4 April 2007. In this study we extended the analyses to a Landsat TM scene from 8 December 2001 (path 232, row 89). For consistency between the different satellite images, all sets were rectified using the 1987 Landsat scene as a reference.
Due to the large inter-annual variability in temperature and precipitation in this portion of the Andes, the ELA of the glacier under study probably fluctuates widely from year to year. In the absence of direct measurements, this important parameter can be estimated based upon the assumption that the snow line at the end of the summer (February-March) is related to the ELA (Rivera et al., 2002). We were able to identify and digitize the snowline (Cogley et al., 2011) in the 16 February 1972 aerial photo, in the 9 February 1987 TM scene, and in the 4 April 2007 Aster scene. As these images were taken in the mid-late summer, the snowline altitude was used as a rough approximation of the ELA at the glacier in these particular years. In other cases the low contrast of the images precluded the identification of the snowline.

For years prior to the remote sensing era, when it was not possible to determine glacier limits over the entire perimeter, we assumed a constant accumulation area derived from the 1987 inventory. Based on this assumption, areal variations in earlier decades and centuries would thus be due only to changes in the ablation area. In cases where portions of the lateral and frontal moraines were not preserved, the glacier margin was linearly interpolated between moraine fragments along the valley sides. Historical photographs and documents were used to locate the frontal position of the glacier in earlier decades and also as an independent source of evidence to corroborate the mapping derived from dendrogeomorphological and remote sensing analyses. In particular, we found two very useful photographs of the glacier, one from the climber and explorer Dr. Juan Javier Neumeyer (Neumeyer, 1949), who visited and mapped the area in 1948 


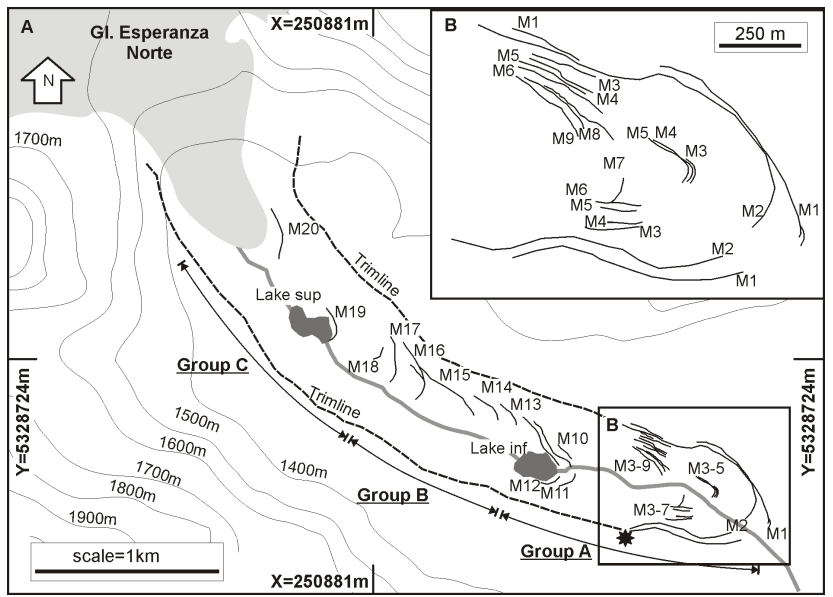

Fig. 4. (A) Simplified geomorphological map of the upper Esperanza Norte valley. Moraine crests are shown as black lines, moraine groups are also shown. The black asterisk shows the location from where the panorama view of Fig. 2 was taken. (B) A closer view of the moraines associated with the maximum LIA glacier extent. Coordinates X and Y in UTM 19 S WGS84 projection.

(a paired comparison with a 2001 photo was established by Masiokas et al., 2008), and another photo taken in 1978 during the field surveys of a preliminary glacier inventory developed for the north Patagonian Andes (Rabassa et al., 1978b). Additional material and field measurements were collected in 1996, 2001 and 2010 during the geomorphological and dendrochronological studies conducted at GEN.

\section{Results}

\subsection{Moraine mapping and geomorphic description of the glacier forefield}

In the upper valley of Río Esperanza Norte, 20 different moraine systems were recognized in the forefield of GEN and labeled with consecutive numbers (Figs. 2 and 4). M1 refers to the outermost crest and M20 to the innermost crest, the nearest to the present glacier front. Based on the position of the moraines, their relative relief, grain size, and clast shape and lithology, we were able to identify three main groups. Large rock avalanches have removed most morainic deposits on the south side of the valley and therefore the discussion regarding the moraine characteristics is based mainly on evidence collected on the northern slope (Figs. 2 and 4).

The outermost group of moraines (Group A; M1 to M13) have in general rounded profiles, low relief, and are largely composed of medium to large, sub-rounded granodiorite clasts. M1 is associated with a visible trimline along the valley sides (Figs. 2, 4a and b). M1 to M9 constitute a compact set of crests along the south side of the valley (Fig. 4b). The moraine crests appear curved in plan view, and have a common pattern in which each crest is invariably at a lower

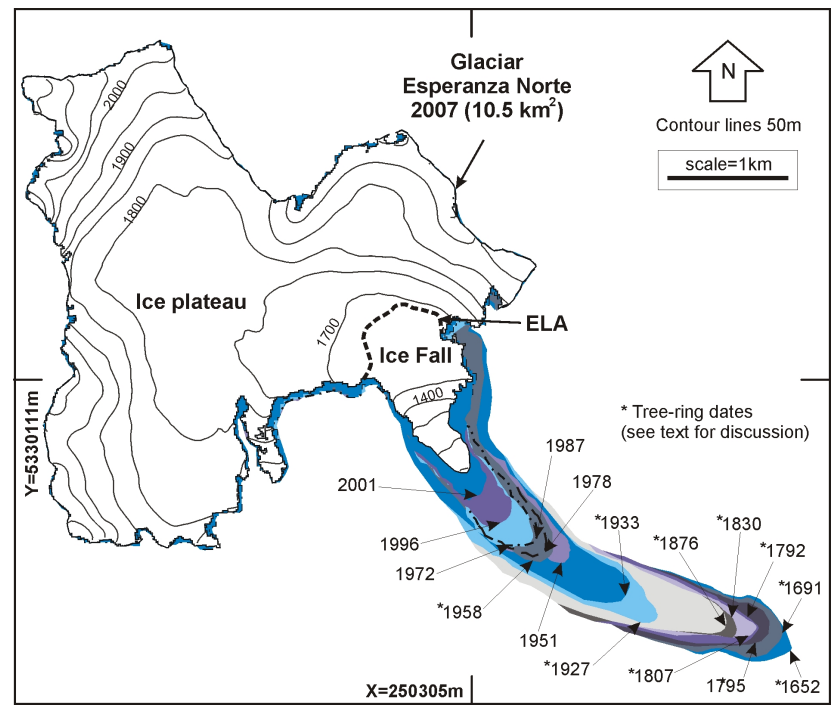

Fig. 5. Reconstruction of LIA and post-LIA fluctuations of Glaciar Esperanza Norte based on dendrogeomorphological dating of moraines, remote sensing and historical photographs. ${ }^{*}$ Tree-rings dates have inherent assumption and corrections, see Table 1 and Fig. 6. Note the position of the ELA in 2007 (dotted line) and the location of the ice fall that characterizes the longitudinal profile of the glacier. Thin black lines indicate elevation contour lines, for simplicity only a few are labeled. Coordinates X and Y in UTM 19 S WGS84 projection.

elevation than the crest located immediately upslope. However, in places it is very difficult to differentiate between these different crests. The inner M10 to M13 are more widely spaced and M12 constitutes a natural dam for a proglacial lake located in the lowest part of the valley (Lake Inf., Figs. 2 and 4). The moraines of an inner group (Group B; M14 to M16) located at the bottom of the valley, have a general hummocky relief, and are composed of medium to large, angular to very angular gabroic clasts. Except for M16 which is located transverse to the valley, the remains of M14 and M15 run largely parallel to the valley side (Figs. 2 and 4). Group C of moraines includes M17 to M20. These innermost moraines have sharp crests and are located in the lower part of the valley (Figs. 2 and 4). The crests have low relative relief and are composed of diamicton, with a silt matrix, and angular to sub-rounded granodiorite and gabroic clasts. In addition to moraine crests, other relevant landforms were also recognized during remote sensing analyses and field surveys. Scree cones and rock avalanches are present on both sides of the valley and have affected different portions of the moraines described above. These features are very active and their origin could be associated with the gradual disappearance of the glacier tongue over the last few centuries, which resulted in a release of the pressure of the glacier against the valley walls (Fig. 2). The massive earthquake centered in Valdivia, Chile in 1960 affected the study area (Villarosa et al., 2009) and may have triggered the formation of many of 

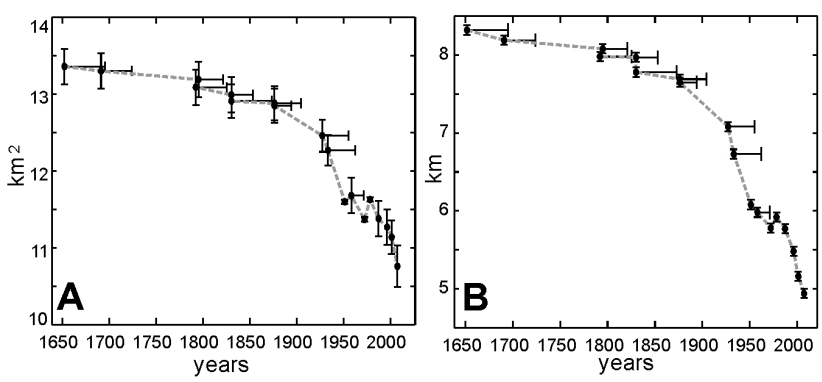

Fig. 6. Variations in area (A) and length (B) of Glaciar Esperanza Norte since the LIA. Horizontal error bars (dating uncertainties of the moraines) were estimated based on the difference between their minimum age obtained after corrections and the innermost ring date observed in the tree-ring samples (see Sect. 4 for further discussion). Area and length inaccuracies (vertical error bars) reflect the spatial resolution of the information available (see Table 2).

these features as evidenced by the important differences observed between the 1951 and 1972 aerial photographs. Three main outwash terraces were also recognized during our visits, the larger one located on both sides of the valley and merging with the outermost moraines (M1-M2). A smaller, inner outwash terrace is associated with M3-M5 and another terrace was found in association with the moraines that are closing the lower lake (M10-M13). A small delta plain currently filling the lower lake provides evidence upon which it is possible to infer the original extent of the lake. Río Esperanza Norte, originating in the lower lake, has created a trenched braided fluvial plain that cuts the outer outwash terraces (Fig. 2).

\subsection{ELA and estimation of the Accumulation Area Ratio (AAR)}

The ELA of GEN for the summers of 1972, 1987 and 2007 was estimated at $1568 \pm 30 \mathrm{~m}, 1623 \pm 40 \mathrm{~m}$ and $1645 \pm 40 \mathrm{~m}$, respectively. Although the gradual increase in ELA over time suggests an overall negative mass balance trend for the last $35 \mathrm{yr}$, detailed mass balance measurements over a period of several years are needed before a representative ELA can be determined for this glacier. Nevertheless, using the ELA estimation for 2007 (ca. 1645 m elevation) and the areal distribution at different elevations (i.e. the glacier hypsometry), we found that the Accumulation Area Ratio (AAR, a parameter representing the proportion of the accumulation area over the total area of a glacier) in 2007 was ca. 0.85 . The hypsometry of the glacier basin (Rivera et al., 2011) indicates that most of the area is concentrated in a relatively flat plateau above a steep, 200-m high ridge (Figs. 2 and 5). Presently the ELA is located only $60 \mathrm{~m}$ above this ridge and the small ablation zone of the glacier is concentrated at and below a steep icefall formed on this ridge (Fig. 5).

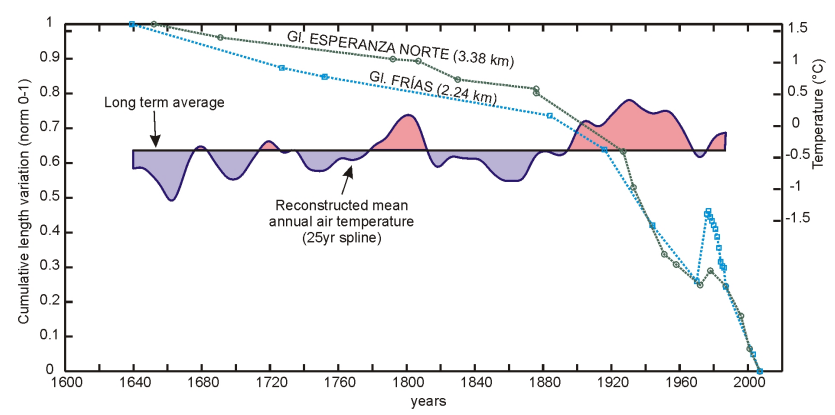

Fig. 7. Comparison of the frontal variations of Glaciar Esperanza Norte (green dashed line) and Glaciar Frías (blue dashed line) between their LIA peak extent and 2007. Both records have been normalized to facilitate the comparison, with the total cumulative length reduction indicated in parentheses in each case. The interpolation lines connecting dates of glacier position are drawn to facilitate the analysis but do not suggest linear trends between adjacent data points. However, note the similarity in the general shape of these curves. Also shown is a smoothed version of a mean annual (April-March) temperature reconstruction developed for northern Patagonia (Villalba et al., 2003). Glacier variations during the past four centuries seem consistent with the temperature reconstruction showing cold conditions from $1640 \mathrm{AD}$ to 1850 , followed by a warming trend from the 1850 s to 1930 s, a period of moderate cooling from the 1940 s to mid 1970 s, and a return to warmer conditions in the last decades.

\subsection{Reconstruction of glacier front and areal variations since the LIA}

Table 1 shows the minimum ages of GEN moraines derived from tree-ring counts. Note that not all moraines identified in the field were vegetated and thus they could not be dated using this technique. The reconstructed frontal position, area and the corresponding date for each moraine are indicated in Fig. 5. The outermost moraine associated with the maximum LIA expansion (M1, Figs. 3a, b, and 5) was already free of ice by the mid 17 th century, providing a minimum date for this event. The tree-ring dating of inner moraines indicates that M2 was formed shortly after M1 during the late 17th century, whereas M3 to M9 were formed between the late 18th and the late 19th centuries (Fig. 5). The minimum corrected tree-ring dates obtained for some of these moraines (e.g. M4, M6 and M9, Table 1) were similar or slightly older to those obtained for their corresponding, outer counterparts. The similarity in age suggests that the moraines were formed within a relatively short period of time - probably within a few decades - which is shorter than the inherent uncertainties associated with the tree-ring dating technique used in this study. M12 and M13 were likely formed in the first decades of the 20th century. As described above, an inner small morainic ridge (M17) was dated to 1958 based on the age of five young trees associated with this deposit (Table 1 and Fig. 3b). 

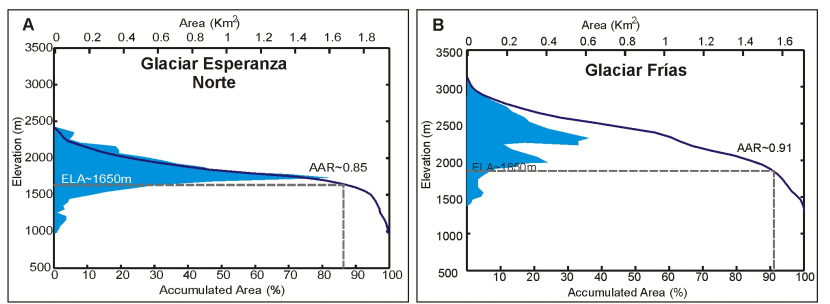

Fig. 8. Comparison of the hypsometry of Glaciar Esperanza Norte and Glaciar Frías. The elevation data were derived from the SRTM V4 Digital Elevation Model. Blue areas indicate the distribution of glaciated area with elevation in the year 2007 and purple lines indicate cumulative surface areas for each glacier. Note the elevated AAR values determined for both glaciers.

Table 2 and Fig. 6 show the records of glacier length and areal fluctuations of the past $400 \mathrm{yr}$. During the LIA, GEN reached a maximum length of approximately $8.32 \mathrm{~km}$ and an area of $13.36 \mathrm{~km}^{2}$, whereas currently (2007) the glacier is about $4.94 \mathrm{~km}$ long and covers an area of $10.76 \mathrm{~km}^{2}$. Errors associated with these length and area estimations were calculated taking into account the characteristics of the base images used for digitizing the glacier outline and main moraines in the forefield (Table 2). The areal errors associated with measurements made on Landsat and Aster images are determined by the spatial resolution of these images $(30 \mathrm{~m}$ and $15 \mathrm{~m}$, respectively) and the perimeter of the glacier under investigation. Aerial photographs generally have a better spatial resolution than Landsat and Aster scenes. However, due to the deformation of these photos and the various changes introduced when transferring the photos into a regular cartography, the areal errors can be substantially higher. In this study the errors associated with measurements based on aerial photographs were increased to match those of Landsat scenes (see Table 2). Both records - length and area - follow a similar pattern, indicating a progressively shorter and smaller glacier over the past $400 \mathrm{yr}$ (Fig. 6). This similarity is likely due to the particular morphology of the glacier, where areal and frontal variations are almost exclusively determined by the expansion or contraction of the narrow glacier tongue located below the icefall and contained within the valley sides (Fig. 5). No major changes at the upper portions of the glacier were detected in the aerial photographs and satellite images available. Although it is impossible to reproduce the post-LIA areal changes at the upper portion of the glacier from the moraine records alone, we assume that the surface covered by this sector has remained relatively unchanged over the past centuries. An ice divide migration is unlikely because the glacier's basin is surrounded by higher peaks and ridges, but we cannot discard the possibility of ice elevation changes (thinning) at the accumulation zone concurrent with the observed frontal retreat of the glacier over the study period.

A field photograph from Rabassa et al. (1978b) shows the glacier front in a more advanced position in 1978 than that
Table 2. Length and area reconstructions for Glaciar Esperanza Norte. Length measurements have a constant 60-m error (two Landsat pixels), whereas areal measurements have a variable error based on the perimeter of the glacier and the spatial resolution of the material used in each case.

\begin{tabular}{llll}
\hline Position & Length $(\mathrm{km})$ & Area in $\mathrm{km}^{2}$ (error) & Date $(\mathrm{yr}$ AD) \\
\hline M1 & 8.32 & $13.36(0.23)$ & $1652^{*}$ \\
M2 & 8.19 & $13.30(0.23)$ & $1691^{*}$ \\
M3 & 8.08 & $13.19(0.23)$ & $1795^{*}$ \\
M4 & 7.98 & $13.09(0.23)$ & $1792^{*}$ \\
M5 & 7.97 & $12.99(0.23)$ & $1830^{*}$ \\
M6 & 7.96 & $13.03(0.23)$ & $1807^{*}$ \\
M7 & 7.78 & $12.91(0.22)$ & $1830^{*}$ \\
M8 & 7.69 & $12.88(0.22)$ & $1876^{*}$ \\
M9 & 7.65 & $12.85(0.22)$ & $1876^{*}$ \\
M12 & 7.08 & $12.46(0.21)$ & $1927^{*}$ \\
M13 & 6.73 & $12.27(0.20)$ & $1933^{*}$ \\
Aerial photograph 1951 & 6.08 & $11.60(0.23)$ & 1951 \\
M17 & 5.98 & $11.68(0.23)$ & $1958^{*}$ \\
Aerial photograph 1972 & 5.78 & $11.37(0.23)$ & 1972 \\
Field photograph 1978 & 5.92 & $11.63(0.23)$ & 1978 \\
Landsat 1987 & 5.77 & $11.38(0.23)$ & 1987 \\
Field observation 1996 & 5.48 & $11.27(0.23)$ & 1996 \\
Field observation 2001 & 5.16 & $11.14(0.22)$ & 2001 \\
Aster 2007 & 4.94 & $10.76(0.27)$ & 2007 \\
\hline
\end{tabular}

*The dates of the moraines are minimum age estimations based on tree-ring counts of the oldest trees growing on their surface (see text for further details).

recorded in the aerial photograph of 1972. During this minor readvance, the glacier did not reach M17, which has had trees growing on its surface since at least 1971 (Figs. 3 and 5).

\section{Discussion and conclusions}

The development of detailed records of glacier fluctuations during the past millennium is crucial for a better understanding of the recent glacier and climate history from many remote mountainous regions in the world. Indeed, several studies (see e.g. Leclercq et al., 2011 and references therein) have developed climatic reconstructions from glacier length records, providing independent evidence to validate or corroborate paleoclimatic inferences derived from other type of climate proxies such as tree rings, ice cores, or varved lake sediments. Although long term records of glacier mass balance are ultimately needed to properly disentangle the complex relationships between climate and glacier variations, the use of good quality glacier length records appears as a promising alternative to tackle these challenging issues.

The record of LIA and post-LIA fluctuations of Glaciar Esperanza Norte presented here provides much needed evidence of glacier changes in the northern portion of the Patagonian Andes. The main LIA expansion at this site (M1, Fig. 5) was dated dendrochronologically to the mid 17th century, in good agreement with results obtained at some glaciers further north (e.g. Glaciar Frías in the Tronador area, Fig. 1) and further south in this region (see Masiokas et al., 2009). Between M1 and the adjacent mature forest we found an interesting contrast in the vegetation under the main 
canopy of trees that has also been described at other glaciated sites in northern Patagonia (Masiokas et al., 2010). The feature has been informally labeled "bamboo line", and consists of a clear difference in understorey cover between the relatively bare surface of the outermost moraine and dense bamboo (Chusquea coleau) in the mature forest immediately outside the moraine. It is very interesting to note that, despite having large almost $400 \mathrm{yr}$ old trees growing on its surface, the understorey of the outer moraines has not yet been colonized by the adjacent bamboos which are present in almost every patch of forest outside the glacier forefield. Although finding the causes of this phenomenon is outside the scope of this study, the "bamboo line" certainly deserves further research since this feature could provide a very simple and useful tool to identify and map the limit of LIA glacier advances in this region (Masiokas et al., 2010).

Nineteen subsequent readvances evidenced by moraine crests were identified inside M1 (Fig. 3a). In most cases we were able to estimate minimum ages for the formation of these deposits based on tree-ring counts from trees growing on their surfaces (Table 1, Fig. 5). It is important to note that the accuracy of these estimations is determined by inherent limitations of this particular dating technique and the treering material available. In general, at GEN the dating of older deposits is less accurate than the dating of younger moraines where trees are smaller and it is easier to reach the pith at their base (see Sect. 4). The various corrections applied to the samples (sampling height, pith offset and ecesis; Table 1) are intended to minimize the errors in the estimation of the true age of the moraines, but obviously these minimum age estimates should be treated with caution as it is not currently possible to provide a well verified, calendar date of formation for any of the moraines at GEN. The analyses of the tree-ring evidence currently available shows that M2, a moraine associated with a frontal advance or standstill almost as extensive as M1, was formed probably shortly after M1 during the 17th century. A group of moraine crests (M3-M9; Figs. 2 and $4 \mathrm{~b})$ located relatively close to these maximum LIA moraines were formed over the course of the late 18th - late 19th centuries. This group of closely-spaced moraines is likely the result of a period of several minor readvances and stand-stills of the glacier margin after the peak LIA event. Subsequently the glacier front experienced an important recession until the beginning of the 20th century when it readvanced and formed moraines M10-M13. The inner M14-M20 were formed by several subsequent, progressively less extensive advances or standstills during the mid to late 20th century (Figs. 4a and 5). Examination of aerial and field photographs allowed the identification of a more recent small readvance of the glacier front during the 1970s. Interestingly, the dates of the deposits and the spacing between them suggest that despite experiencing at least four readvances in the last $100 \mathrm{yr}$, the glacier front retreated much more rapidly during the 20th century than over earlier centuries (Figs. 5 and 6). This situation again is similar to that recorded at Glaciar Frías, a glacier of similar size and general characteristics located ca. 110 further north in the Patagonian Andes (Villalba et al., 1990; Zemp et al., 2011).

The comparison of the newly developed record of length fluctuations at GEN (Fig. 7) with an equivalent record from Glaciar Frías (Villalba et al., 1990; Zemp et al., 2011; Leclercq et al., 2011) is interesting because: (a) these two glaciers share a similar history and many morphological characteristics (both have a similar size and grounded, continuous tongues largely devoid of supraglacial debris which expanded into relatively flat, forested valleys during the LIA); (b) they are neither affected by large, deep proglacial lakes, a thick debris cover, nor major topographical obstructions that may have modified or affected substantially their response to climate; and (c) their records of length variations were developed using similar techniques and are the most detailed currently available in southern South America (Masiokas et al., 2009; Zemp et al., 2011). Glaciar Frías is located at higher elevations, further away from the Pacific Ocean and apparently at a drier site than GEN (see below), but nonetheless their variations could be considered relatively free of non-climatic influences and thus reliable indicators of regional climate changes at least at multi-decadal and longer timescales.

Since their peak LIA extent in the early-mid 17th century, both GEN and Glaciar Frías have experienced, in relative terms, a similar pattern of frontal recession (Fig. 7). The gradual retraction of the glaciers' fronts, evidenced by progressively smaller, younger inner moraines and remote sensing determinations, suggests a regional transition towards progressively warmer and drier climate conditions over the past few centuries. Multi-year or multi-decadal periods of relatively cool and/or wet conditions probably interrupted this general climatic trend promoting the advance of glacial fronts and resulting in the formation of numerous moraines identified within the LIA limits at these sites. The clearer example is the recent, small readvance that both glaciers experienced during the late 1970s (Fig. 7), which was carefully monitored and measured at Frías (Villalba et al., 1990; Zemp et al., 2011; Leclercq et al., 2011) and deducted from aerial and historical photographs at GEN. This period of glacial advances has also been identified at other sites in the region in connection with a marked period of cooler and wetter conditions throughout north-western Patagonia (Villalba et al., 2003; Masiokas et al., 2008). Although both glaciers show a concurrent advance in the 1970s (Fig. 7), the advance at Frías was apparently more prominent than that observed at GEN. This could be related to specific differences in glacier morphology, dynamics and/or bed topography, or to differences in the timing of measurements and amount of evidence available at each site: During the late 1970s and until the beginning of the 1980s, the frontal position of Frías was determined annually by field measurements (Villalba et al., 1990; Zemp et al., 2011; Leclercq et al., 2011). In contrast, the advance of GEN during this period was determined using an 
aerial photo from 1972, a field photo from 1978, and a Landsat scene from 1987. It is thus possible that, although showing an advance, the 1978 position of GEN was not the most extensive position in the 1972-1987 period.

The identification of earlier periods with conditions favourable for glacier expansion is more difficult based on the limited evidence available. The set of moraines of the 19th century at GEN may correspond with a major advance dated at Glaciar Río Manso in the Tronador area, a few $\mathrm{km}$ to the south of Glaciar Frías (Masiokas et al., 2010). However, the unique morphological and glaciological characteristics of each ice mass and the lack of detailed climatological and glaciological data make it difficult to connect any particular glacier advance with a specific period of cooler/wetter conditions. In addition to the inherent uncertainties associated with the tree-ring dating of moraines, which in most cases only provide minimum dates of formation for deposits (see e.g. Luckman, 2000; Luckman and Villalba, 2001), another complicating factor is the determination of the relative influence of temperature and precipitation variations in any given period. It is generally assumed that temperature variations are the dominating factor that modulates glacier changes at regional and larger scales. Indeed, Fig. 7 shows that the rapid recession of GEN and Glaciar Frías during the first half of the 20 th century is concurrent with a period of warmer than normal temperatures reconstructed from tree-ring width records, whereas the advances of GEN dated to the 19th century could correspond with an extended period of cooler than normal conditions as inferred from the proxy based reconstruction (Villalba et al., 2003). However, Masiokas et al. (2008) have shown that in this portion of the Andes a marked decrease in winter precipitation over the 20th century has also contributed to explain the recent dramatic ice mass losses observed in this region.

Differences in the hypsometry and morphology of glaciers provide interesting, complementary tools for understanding or characterizing the climatological and glaciological conditions of a site and the way a glacier may respond to specific changes in climate (Furbish and Andrews, 1984; Rivera et al., 2011). Figure 8 shows that the body of GEN is distributed ca. $500 \mathrm{~m}$ lower than Glaciar Frías, which is probably related to the fact that GEN is better protected than Frías from solar radiation (with south-easterly orientation vs. a northerly orientation) and likely receiving higher amounts of precipitation. The difference in hypsometry of these two glaciers suggests that a potential rise/decrease in the $0{ }^{\circ} \mathrm{C}$ isotherm in this region will enhance or mask their response depending on the site. Figure 8 also shows that GEN has a more uneven distribution of glacier area with elevation, concentrating a large portion of the ice between 1500 and $2000 \mathrm{~m}$. This is directly related to the particular morphology of this glacier, which shows a rather large accumulation area forming a relatively flat plateau and a narrow lower tongue confined within steep valley walls. Measurements of the ELA at GEN in 2007 (Fig. 8a) indicate this limit is currently located at $1650 \mathrm{~m}$, already affecting the lower sectors of this small glaciated plateau. In contrast, at Glaciar Frías the ELA in 2007 was determined at around $1850 \mathrm{~m}$ (Fig. 8b). Although both glaciers have large AAR ( 0.85 and 0.91 for GEN and Frías, respectively), the result of an equivalent, potential future rise in the ELA could be more dramatic for GEN as this glacier already has most of its area close to this equilibrium line and thus more ice would be exposed to ablation. In contrast, Frías has a more even distribution of ice with elevation and a potential rise in the ELA would still leave most of its ice above this limit (Fig. 8).

These intrinsic differences may help explain, partly, the discrepancies in moraine timing observed in Fig. 7. As mentioned above, limitations in the methods used to date the moraines may also contribute to the differences recorded in the chronologies of GEN and Glaciar Frías (see e.g. Luckman, 2000; Luckman and Villalba, 2001). Ultimately, these differences highlight the need for more detailed, comprehensive assessments of topographic, glaciological and climatological conditions at the different study sites to better understand the complex relationships existing between glaciers and climate and the challenging task of developing reliable glacier chronologies for the region. The studies available from north Patagonian glaciers show that in this region there is a great potential for developing detailed (i.e. decadal resolution) glacier chronologies since at least the LIA maximum about four-five centuries ago. The records from GEN and Glaciar Frías are fine examples of such chronologies that could probably even be improved with the incorporation of additional dating controls (i.e. subfossil, scarred or tilted trees directly affected by glacier advances, etc) to better pinpoint certain glacier advances. However, even with improved records from these two glaciers, the number of study sites is still too small to discriminate glacier changes induced by specific local conditions from those due to regional scale climate changes across the north Patagonian Andes.

The rich variety of environments in the Patagonian Andes offers the opportunity of integrating different paleoclimatic proxies (tree rings, glacier records, varved lake sediments) to better understand large scale climate changes over the past millennium. In order to take advantage of the full potential of glacier records as paleoclimatic indicators, we believe that, in addition to the development of carefully dated glacier chronologies, representative and continuous networks of glacier mass balance and high elevation meteorological stations are urgently needed. Although recent modelling efforts show promising perspectives (e.g. Leclercq et al., 2011), in situ and continuous glaciological and meteorological measurements are crucial to properly elucidate the specific influence of the main climatic variables (temperature, precipitation) on glaciers and extract robust, regionally representative paleoclimatic information from glaciers in Patagonia. 
Acknowledgements. This research was funded by Agencia Nacional de Promoción Científica (projects PICT 2007-0379, PICTR 02-186, and PICT 2010-1438), the Inter American Institute for Global Change Research (IAI) through projects CRN03 and CRN2047, and the International Association of Sedimentologists (Postgraduate grant to L. Ruiz). We would like to thank the Global and Land Cover Facility and the GLIMS project for facilitating access to satellite images, and A. Ripalta, S. Calí, E. Ferrero, A. de Errasti, D. Falaschi, T. Cerutti and Dirección General de Bosques y Reservas de Chubut for assistance in the field. The comments and suggestions from two reviewers helped to improve the manuscript and are greatly appreciated.

Edited by: A. Rivera

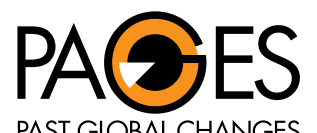

The publication of this article was sponsored by PAGES.

\section{References}

Almeyda, A. E. and Saez, S. F.: Recopilación de datos climáticos de Chile y mapas sinópticos respectivos, Ministerio de Agricultura, Santiago, Chile, 1958.

Bown, F. and Rivera, A.: Climate changes and recent glacier behaviour in the Chilean Lake District, Global Planet. Change, 59, 79-89, 2007.

Carrasco, J., Quintana, J., and Casassa, G.: Changes of the $0{ }^{\circ} \mathrm{C}$ isotherm and the equilibrium line altitude in central Chile during the last quarter of the 20th century, Hydrolog. Sci. J., 50, 933948, 2005.

Carrasco, J., Osorio, R., and Cassasa, G.: Secular trend of equilibrium-line altitude on the western side of the southern Andes, derived from radiosonde and surface observations, J. Glaciol., 54, 538-550, 2008.

Cogley, J. G., Hock, R., Rasmussen, L. A., Arendt, A. A., Bauder, A., Braithwaite, R. J., Jansson, P., Kaser, G., Möller, L., and Zemp, M.: Glossary of Glacier Mass Balance and Related Terms, IHP-VII Technical Documents in Hydrology No. 86, IACS Contribution No. 2, UNESCO-IHP, Paris, 114 pp., 2011.

Condom, T., Coudrain, A., Sicart, J. E., and Théry, S.: Computation of the space and time evolution of equilibrium-line altitudes on Andean glaciers $\left(10^{\circ} \mathrm{N}-55^{\circ} \mathrm{S}\right)$, Global Planet. Change, 59, 189202, 2007.

Falvey, M. and Garreaud, R. D.: Regional cooling in a warming world: Recent temperature trends in the southeast Pacific and along the west coast of subtropical South America (1979-2006), J. Geophys. Res., 114, D04102, doi:10.1029/2008JD010519, 2009.

Furbish, D. J. and Andrews, J. T.: The use of hypsometry to indicate long-term stability and response of valley glaciers to changes in mass transfer, J. Glaciol., 30, 199-211, 1984.

Gallopín, G. C.: Estudio ecológico integrado de la cuenca superior del Río Manso Superior (Río Negro, Argentina). I. Descripción general de la cuenca, Anales de Parques Nacionales 14, 161-230, 1978.

Garibotti, I., A. and Villalba, R.: Lichenometric dating using Rhizocarpon subgenus Rhizocarpon in the Patagonian Andes, Ar- gentina, Quaternary Res., 71, 271-283, 2009.

Garreaud, R., Vuille, M., Compagnucci, R., and Marengo, J.: Present-day South American climate, Palaeogeogr. Palaeocl., 281, 180-195, 2009.

Gonzáles Ferrán, O.: Volcanes de Chile, Santiago, Instituto Geográfico Militar, 635 pp., 1995.

Grove, J. M.: The Little Ice Age, London, Methuen, 1988.

Haeberli, W.: Accelerated glacier and permafrost changes in the Alps, Mountain Environments in Changing Climates, edited by: Beniston, M., Routledge, London, 91-107, 1994.

IPCC: Climate Change 2007: The Physical Science Basis. Contribution of Working Group I to the Fourth Assessment Report of the Intergovernmental Panel on Climate Change, edited by: Solomon, S., Qin, D., Manning, M., Chen, Z., Marquis, M., Averyt, K. B., Tignor, M., and Miller, H. L., Cambridge University Press, Cambridge, United Kingdom and New York, NY, USA, 996 pp., 2007.

Jarvis, A., Reuter, H. I., Nelson, A., and Guevara, E.: Holefilled SRTM for the globe Version 4, CGIAR-CSI SRTM $90 \mathrm{~m}$ Database, available at: http://srtm.csi.cgiar.org (last access: June 2010), 2008.

Leclercq, P. W. and Oerlemans, J.: Global and hemispheric temperature reconstruction from glacier length fluctuations, Clim. Dynam., 38, 1065-1079, doi:10.1007/s00382-011-1145-7, 2011.

Leclercq, P. W., Pitte, P., Giesen, R. H., Masiokas, M. H., and Oerlemans, J.: Climatic interpretation of the length fluctuations of Glaciar Frías, North Patagonia, Argentina, Clim. Past Discuss., 7, 3653-3697, doi:10.5194/cpd-7-3653-2011, 2011.

Lliboutry, L.: Nieves y glaciares de Chile, Fundamentos de Glaciología, Universidad de Chile, 472 pp., Santiago de Chile, 1956.

Lliboutry, L.: Glaciers of Chile and Argentina. Satellite image atlas of glaciers of the world, South America, edited by: Williams, R. S. and Ferrigno, J. G., USGS, Denver, USA, 1386-I, 1999.

Luckman, B. H.: The Little Ice Age in the Canadian Rockies, Geomorphology, 32, 357-384, 2000.

Luckman, B. H. and Villalba, R.: Assessing the synchroneity of glacier fluctuations in the Western Cordillera of the Americas during the last millennium, Interhemispheric climate linkages, edited by: Markgraf, V., Academic Press, San Diego, 119-140, 2001.

Masiokas, M. H., Villalba, R., Luckman, B. H., Lascano, M. E., Delgado, S., and Stepanek, P.: 20th-century glacier recession and regional hydroclimatic changes in northwestern Patagonia, Global Planet. Change, 60, 85-100, 2008.

Masiokas, M. H., Rivera, A., Espizua, L. E., Villalba, R., Delgado, S., and Aravena, J. C.: Glacier fluctuations in extratropical South America during the past 1000 years, Palaeogeogr. Palaeocl., 281, 242-268, 2009.

Masiokas M. H., Luckman B. H., Villalba, R., Ripalta, A., and Rabassa, J.: Little Ice Age fluctuation of Glaciar Río Manso in the north Patagonian Andes of Argentina, Quaternary Res., 73, 96-106, 2010.

McCarthy, D. P. and Luckman, B. H.: Estimating ecesis for treering dating of moraines: a comparative study from the Canadian Cordillera, Arctic Alpine Res., 25, 63-68, 1993.

Miller, A.: The climate of Chile, Climates of Central and Southern America, edited by: Schwerdtfeger, W., Elsevier, Amsterdam, 113-145, 1976. 
Neumeyer, J. J.: En el valle del Río Esperanza (Chubut), Anuario del Club Andino Bariloche, 17, 47-50, 1949.

Oerlemans, J.: Extracting a climate signal from 169 glacier records, Science, 308, 675-677, 2005.

Prohaska, F.: The climate of Argentina, Paraguay and Uruguay, Climate of Central and South America, edited by: Schwerdtfeger, E., World Survey of Climatology, Elsevier, Amsterdam, 57-69, 1976.

Rabassa, J., Rubulis, S., and Suarez, J.: Los glaciares del Monte Tronador, Anales de Parques Nacionales, XIV, 259-318, 1978a.

Rabassa, J., Rubulis, S., and Suárez, J.: Glacier Inventory of the northern Patagonian Andes, Argentina between latitude $39^{\circ} \mathrm{S}$ and latitude $42^{\circ} 20^{\prime} \mathrm{S}$, Internal report to the Temporary techinical Secretariat (TTS) for World Glacier Inventory, Swiss Federal Institute of techonology, Zürich, 1978b.

Rabassa, J., Brandani, A., Boninsegna, J. A., and Cobos, D. R.: Cronología de la "Pequeña Edad del Hielo" en los glaciares Río Manso y Castaño Overo, Cerro Tronador, Provincia de Río Negro, Actas Noveno Congreso Geológico Argentino, 3, 624-639, 1984.

Rivera, A., Acuña, C., Casassa, G., and Bown, F.: Use of remotely sensed and field data to estimate the contribution of Chilean glaciers to eustatic sea-level rise, Ann. Glaciol., 34, 367-372, 2002.

Rivera, A., Bown, F., Mella, R., Wendt, J., Casassa, G., Acuña, C., Rignot, E., Clavero, J., and Brock, B.: Ice volumetric changes on active volcanoes in southern Chile, Ann. Glaciol. 43, 111-122, 2006.

Rivera, A., Cawkwell, F., Rada, C., and Bravo, C.: Hypsometry, Encyclopedia of Snow, Ice and Glaciers, edited by: Singh, V. P. and Haritashya, U. K., Springer, The Netherlands, 551-445, 2011.

Rivera, A., Bown, F., Carrión, D., and Zenteno, P.: Glacier responses to recent volcanic activity in Southern Chile, Environ. Res. Lett., 7, 014036, doi:10.1088/1748-9326/7/1/014036, 2012.
Ruiz, L.: Geomorphic, sedimentologic and crono-stratigraphy analysis of glacial, periglacial and glacigenic deposits, Southern Andes Range and near zones, between $42^{\circ}$ and $43^{\circ} \mathrm{S}$, from the last glaciation to the present time, Phd Thesis, Universidad de Buenos Aires, in preparation, 2012.

Sigafoos, R. S. and Heindricks, E. L.: The time interval between stabilization of alpine glacial deposits and establishment of tree seedlings, US Geological Survey, Professional Paper 650-B, 8993, 1969.

Stokes, M. A. and Smiley, T.: An Introduction to Tree-Ring Dating, University of Arizona Press, Tucson, Arizona, 73 pp., 1996.

Tucker, C. D., Grant, D., and Dykstra, J.: NASA global orthorectified Landsat Data set, Photogramm. Eng. Rem. S., 70, 313-322, 2004.

Villalba, R., Leiva, J. C., Rubulis, S., Suarez, J., and Lenzano, L. E.: Climate, tree-ring, and glacial fluctuations in the Río Frías Valley, Río Negro, Argentina, Arctic Alpine Res., 22, 215-232, 1990.

Villalba, R., Lara, A., Boninsegna, J. A., Masiokas, M., Delgado, S., Aravena, J. C., Roig, F., Schmelter, A., Wolodarsky, A., and Ripalta, A.: Large-scale temperature changes across the Southern Andes: 20th-century variations in the context of the past 400 years, Climatic Change, 59, 177-232, 2003.

Villarosa, G., Outes, V., Gomez, E. A., Chapron, E., and Ariztegui, D.: Origen del tsunami de mayo de 1960 en el Lago Nahuel Huapi, Patagonia: aplicación de técnicas batimétricas y sísmicas de alta resolución, Rev. Asoc. Geol. Argent., 65, 593-597, 2009.

Zemp, M., Zumbühl, H. J., Nussbaumer, S. U., Masiokas, M. H., Espizua, L. E., and Pitte, P.: Extending glacier monitoring into the Little Ice Age and beyond, PAGES News, 19, 67-69, 2011. 